** IN PRESS 2020 INTERNATIONAL JOURNAL OF MULTILINGUAL AND

MULTICULTURAL DEVELOPMENT **

Intersections of official and family language policy in Quebec

Susan Ballinger, McGill University

Melanie Brouillard, Concordia University

Alexa Ahooja, McGill University

Ruth Kircher, Mercator European Research Centre on Multilingualism and Language Learning, Fryske Akademy

Linda Polka, McGill University

Krista Byers-Heinlein, Concordia University

Susan Ballinger

Faculty of Education

Room 244

3700, rue McTavish

Montreal, QC H3A 1Y2 


\title{
Intersections of official and family language policy in Quebec
}

\author{
Abstract \\ The current paper describes a study that sought to determine the beliefs, practices, and \\ needs of parents living in Montreal, Quebec, who were raising their children \\ bi/multilingually. The parents $(\mathrm{N}=27)$ participated in a total of nine focus group and \\ individual interviews in which they discussed their family language policies (language \\ ideologies, practices, and actions taken to maintain a language). Through rounds of \\ deductive and inductive coding and analysis, family language policies regarding English \\ and/or French were compared with policies regarding heritage languages. The participants' \\ family language policies were further examined in light of Quebec's official language \\ policy of interculturalism. Findings indicate a complex co-existence of family and official \\ language policy in which parents both support Quebec's official language policy by \\ converging towards French as a common public language and questioning the policy's \\ stance on official institutional support for heritage languages.
}

Key Words: heritage languages, minority languages, language attitudes, plurilingualism, language policy, language maintenance

\section{Introduction}

The study of family language policy (FLP) is based on Spolsky's (2004) framework for language policy, which includes beliefs about language(s), language practices, and actions taken to maintain language(s) (King and Fogle 2013; King, Fogle, and Logan-Terry 2008; Spolsky 2004). Studies examining FLP span the past four decades, and have included case 
studies of family language use patterns in the home (Gafaranga 2010; Lanza 2007), societal and cultural influences on FLP (Curdt-Christiansen 2009; Okita 2001; Piller and Gerber 2018), and FLP's impact on children's language proficiency and cultural-linguistic identity (Ren and $\mathrm{Hu} 2013$ ). In the past, FLP studies have tended to focus on households with two European languages, where parents had adopted a one-parent-one-language approach. However, more recent studies have examined more diverse families (King 2016), including families raising children with more than two languages, families who speak non-European languages, refugee families (Revis 2017), adoptive families (Fogle 2013), and families employing a wider range of language use practices than one-parent-one-language (Slavkov 2017).

This paper describes a study that sought to determine the beliefs, practices, and needs of parents in Montreal, Quebec, who were raising their infants and toddlers bi/multilingually. These parents participated in interviews in which they discussed their language ideologies, the steps they were taking to support their child's language development, and their questions and concerns about raising a child to be a successful communicator in more than one language. Because of the participants' diverse backgrounds, this study offers a unique opportunity to compare the perspectives of families towards raising their children in the official societal languages, French and English, with their perspectives towards raising their children in at least one heritage language. Here, heritage languages are defined as 'languages other than the dominant language (or 
languages) in a given social context' (Kelleher 2010, 1) $)^{1}$. In the Quebec context, therefore, a heritage language would be any language other than French or English.

\section{Context}

The city of Montreal, Quebec, represents a complex and diverse language environment that is difficult to describe without examining its place within the concentric circles of the North American, Canadian, and Quebec contexts. Canada has two official languages - English and French - and the government works to promote English-French bilingualism in the country. Although home language use is only one way of operationalising bilingualism (Surrain and Luk 2019), it does give some insight into the status of Canada's official languages inside and outside of Quebec. Outside of Quebec, 91.2\% of Canadians claim English as one of their home languages, and $4.2 \%$ claim French. In contrast, French is the only official language in Quebec, and 87.1\% of Quebecers claim French as one of their home languages, while 19.2\% claim English (Statistics Canada 2016). English is granted official minority language status in Quebec by the Canadian federal government and, as such, receives certain protections, including provision of English language schools to certain populations.

The de facto status of English and French in Quebec society is not easily defined. English does not behave like a typical minority language due to its international prestige and majority language status in Canada and the United States. English popular culture plays an important role in Quebec society, and English-speaking communities dot the province.

\footnotetext{
${ }^{1}$ The term minority language is often used synonymously with heritage language. However, because English has official minority language status in Quebec, in this paper, we have chosen to use the term heritage language to avoid confusion.
} 
The greatest concentration of anglophones reside in the Montreal area. In fact, the Englishspeaking minority in Montreal historically constituted the province's social and economic elite, and for a long time, Francophones were obliged to learn and use English if they wanted to achieve upward mobility (e.g. Bernard 2008). This changed as a result of the Charter of the French Language, which was implemented in 1977 and led to a noticeable francisation of Quebec society (e.g. Levine 1990).

More recently, researchers have remarked on the fluidity of English and French status in Montreal, which tends to vary depending on the local community and individual social interactions (Author 1 2017; Godfrey-Smith 2015; Heller 2007; Lamarre 2013). On the one hand, the existence of primarily English or French communities in the Montreal area make it possible for some to live their life surrounded by one language and isolated from the other. The 'two solitudes' characterization of English and French holds in these cases (MacLennan 1945). On the other hand, based on friendships, workplace environment, and home languages, many Montrealers fluidly travel back and forth between English and French or other languages in their daily lives.

In addition to the co-existence of English and French in Quebec society, high immigration rates mean that the province is increasingly linguistically and culturally diverse. Quebec society has long relied on immigration for continued population growth (Bakshaei 2015), and in 2017, more than 30\% of all Quebec births included at least one parent who was a first-generation immigrant (ISQ 2018). The greatest concentration of linguistic diversity is in Montreal, where more than $21 \%$ of all residents speak at least three languages, making it Canada's most trilingual city (Statistics Canada 2016). Greek-, Italian-, Portuguese-, Haitian Creole-, and Hebrew-speaking communities long-ago put 
down roots in the city. Today, Spanish, Arabic, and Italian are the most widely spoken, with the Indian languages Malayalam, Telugu, and Marathi being the fastest growing. Although the city is historically known for its bilingualism, it is increasingly defined by its multilingualism.

\section{The role of FLP in language maintenance and language shift}

According to Fishman's long-standing, three-generation model of immigrant language shift (1991, 2001), the first generation of immigrants introduces a new societal language into the household, the second generation grows up bi/multilingual in the heritage and societal languages, and the third generation is raised monolingually in the societal language

(Fishman 1991). The process could be faster or slower depending on factors such as the size of the local heritage language community or contact with the homeland. The key, however, is that without intergenerational transmission of the heritage language, language shift to majority societal languages will occur.

Investigations of FLP have frequently examined factors that support or prevent language shift over time, both in migrant and multilingual communities. Factors internal to the family have been examined, such as conflicting ideologies between family members (Piller and Gerber 2018) as well as language configurations and language use patterns within the household (Slavkov 2017). In a study of Kinyarwanda-French households in Belgium, Gafaranga (2010) examined how shift occurs in a micro-analysis of daily parentchild interactions, focusing on children's use of French in response to parents' and community members' use of Kinyarwanda. Since adults tended to follow the child's lead 
by switching to French during the interactions, Gafaranga concludes that this analysis allows us to see families and communities "talk language shift into being" $(2010,241)$.

Based on the argument that literacy activities and practices reflect cultural identity (Ferdman 1990), some FLP studies have examined the role of family literacy practices on heritage language maintenance. Curdt-Christiansen's (2009) ethnographic study of FLP among Chinese immigrant families in Quebec focused on their literacy ideologies and practices. Parents in the study noted the importance of heritage language literacy, not only for developing the heritage language, but also for passing on culture through Chinese art and literature. Patrick, Budach and Muckpaloo (2013) documented literacy activities in an Inuit literacy centre in Ottawa, Canada, demonstrating the importance of institutional literacy support in revitalizing and maintaining the Inuit language in family domains.

Studies investigating interactions between FLP and formal education have shown the central role that schooling plays in the language socialization and language attainment of bi/multilingual children. Official-language schooling has often been found to create a conflict between the heritage language and the official majority language (Spolsky 2012). As King et al. $(2008,7)$ contend, "[f]amily patterns of language use and acquisition are both reflected in and reflective of societal patterns." They note that multiple studies have demonstrated how school-aged children's language socialization influences the family to increasingly speak the societal language in the home (De Houwer 2009; Bayley and Schecter 2003; Tuominen 1999). In a survey study of 170 school-age children growing up bi/multilingually in Ontario, Canada, Slavkov (2017) reports on a more complex phenomenon of parental language choice interacting with school choice, where. attending minority language (French) schools and extracurricular heritage language schools were 
predictors of multilingualism. Slavkov concludes that more access to minority (French) and heritage language schools is necessary to meet Canadian goals of official language bilingualism and support for multilingualism.

\section{Interculturalism as language policy}

Since 1971, the Canadian government has officially committed to a policy of multiculturalism, which supports diversity and the equality of all languages and cultures while promoting English-French bilingualism and biculturalism. The situation in Quebec is different. As Louise Beaudoin, a member of the nationalist Parti Québécois once put it succinctly, ' ...multiculturalism is not a Quebec value.' (Beaudoin as cited in Kay 2011). Language policy in Quebec is based on the framework of 'interculturalism', which maintains French as the langue publique commune, or the 'common public language,' for public schools, government institutions, and the workplace, while officially supporting diversity as an essential characteristic of the province and condemning cultural discrimination (Bouchard 2012; Rocher et al 2007). As Anctil (1996, 143) explains, this model aims to achieve 'the meeting of cultures, their mutual interpenetration and the reciprocal recognition of their respective contributions, within a common civic culture and a French-speaking framework.'

An important piece of the ideology underlying Quebec's language policy is the notion that French language and culture are constantly under threat from internal and external forces (Bourhis and Sioufi 2017; Oakes and Warren 2007). Such a cultural and linguistic insecurity is, in fact, a common sentiment among minority nations (Turgeon and Bilodeau 2014). As noted above, historically, French was threatened by the power and 
influence of anglophones in the province. The Quiet Revolution of the 1960s and the subsequent language legislation from the 1970s onwards shifted power to the hands of francophone Quebeckers. However, nationalist discourse holds that the language and culture continue to be under threat from anglophone influence because English has continued to grow in prestige, is the language of upward mobility in most of North America, and it has become a global lingua franca (Stefanescu and Georgeault 2005; Author 4 2016).

Immigrants have been portrayed by certain nationalists as particularly threatening to French language and culture. Historically, they threatened to tip the scales in favour of English by sending their children to English-speaking schools (e.g. Levine 1990; Author 4 2016). As a result, since the Charter of the French Language was passed in 1977, most Quebec immigrants are required by law to attend French schools. According to some, they have thus become 'fodder for the survival and future of French language and culture' (Crump 2017, 155). According to others, Quebec aims to provide its newcomers with 'the "key to the house" - that is, the French language - so that they can make themselves totally at home' (Oakes and Warren 2007, 149).

Quebec has both an English and a French public school system, but only children with parents who have attended English schools in Canada (or whose older siblings have received English schooling in Quebec) are eligible to enrol in English schools. Second language education options are available in both systems, but fully bilingual education only exists in the English system. Some heritage language education options also exist. Under the programme d'enseignement des langues d'origines, or the Heritage Language Instruction Program, funded by the Quebec Ministry of Education, extracurricular heritage 
language instruction is offered in some cases. As for other literacy resources, libraries and book stores usually have both a French and an English section, the size of which depends on the demographics of the local community. Bilingual books and books in heritage languages can be found in a few libraries, but usually in very small numbers.

Spolsky $(2012,3)$ argues that '[e]ach domain within a sociolinguistic ecology has its own variety of language policy, and each influences and is influenced by all other domains'. This dynamic vision of interlocking societal language policies is particularly compatible with societies in which there are high levels of immigration. When the culture and linguistic ideology of recent immigrants encounter those of established communities and existing government language policy, it makes sense to examine the way in which individual FLPs compete with, interact with, or accommodate existing language policies. A full examination of all societal domains is beyond the scope of this study. Nevertheless, by examining how the participants' FLPs both converged with and diverged from the official governmental and institutional policy of interculturalism in Quebec, the study presented here provides meaningful insights as well as clearer direction for future research addressing bi/multilingual parenting needs.

\section{Methodology}

\section{Participants}

A total of 27 parents (mothers $=21$, fathers $=6$ ) from 20 households participated in the interviews, and a range of one to five parents attended each interview. They were recruited from a database of families interested in participating in research, who were identified through government birth lists and community outreach. Participants were screened on the 
phone for whether they met inclusion criteria, specifically that their family self-identified as bi/multilingual, they lived in the Montreal area, they were able to speak and understand English and/or French, and they had a typically-developing first-born child under 3 years of age ( $M=1.72$ years, $S D=0.77$ years). Focusing on parents of first-borns meant that this was their first experience raising a child bi/multilingually, ensuring that their perceptions would not be retrospectively coloured by experience with an older child. Parents were sent a packet after their phone screening, containing the consent form, a questionnaire with standard demographics questions, and the Language Experience and Proficiency Questionnaire (LEAP-Q; Marian, Blumenfeld, \& Kaushanskaya, 2007, see below). The questionnaire also measured mother's highest level of education as a marker of socioeconomic status. Of the 13 mothers included in the questionnaires, all had engaged in some form of post-secondary education, and seven had received a master's degree or higher.

Language background of parents. The parents represented a range of language and cultural backgrounds. Among them, 12 languages were reported to be spoken (see Table 1). Households fell into one of four groups: English-French bilingual (5), English and French plus at least one heritage language (12), French plus at least one heritage language (1), or English plus at least one heritage language (2). We had originally planned for equal sample sizes in each language group, but families often better matched another language group once we received their Language Exposure Questionnaire on the day of their interview, and several other recruited families were unable to attend their scheduled interviews.

\section{Interviews}


Data collection for this study consisted of nine focus group or individual interviews lasting an average of 42 minutes. Initially, only group interviews were planned, but due to a lack of attendance, two of the nine interviews were conducted with individuals. During the interviews, two French-English bilingual researchers led a discussion with parents about their beliefs, concerns, knowledge, resources, feelings, and decisions in relation to raising their children bi/multilingually. Interviews were conducted in English, French, or a mixture of the two. During bilingual interviews, questions were asked in both languages and participants were free to respond in their preferred language. The interviewers read through a list of pre-determined questions (see Appendix A), and participants took turns answering each question. Participants were also encouraged to share additional concerns and ask questions which were not addressed during the sessions at the end of the focus group. Interviews were audio-video recorded for later transcription and analysis.

\section{Interview analysis}

Interviews were transcribed and then analysed through multiple rounds of coding and categorization. First, a round of deductive coding and categorization took place using pre-established codes based on key themes. These codes were cognition (beliefs), affect (feelings), conation (actions or decisions), resources (existing or desired resources for bilingual parenting), concerns, and knowledge (information from referential sources). Then, coded data were re-grouped to examine the specific family language policies (attitudes/ideology, language use, and plans) regarding raising children in English and/or French (societal languages) versus policies regarding raising children with at least one heritage language. The re-organised data were inductively analysed for themes or recurring 
patterns that indicated similarities and differences between FLPs for English, French, and heritage languages. The themes were as follows:

- Beliefs: Tempered optimism about bi/multilingualism,

- Language practices: A 'natural' approach,

- French through schooling; English through media;

- Desire: More bilingual and heritage language options.

The inductive analysis was first conducted separately by three researchers. Then, their observations were compared and discussed by all authors until a final set of themes was agreed upon. Finally, parents' family language policies were examined in light of Quebec's official policy of interculturalism.

\section{Results}

\section{Beliefs: Tempered optimism about bi/multilingualism}

All parents in this study expressed positive beliefs about the benefits of bi/multilingualism and of their child's ability to acquire the household languages. One parent spoke on behalf of her group, 'I think that all of us believe that having more than one language actually opens a lot of doors for opportunities.' Ten families noted the many potential advantages of bi/multilingualism for employment, travel, and ease of communication with others. One parent stated that becoming bi/multilingual now would help their child learn other languages in the future; another mentioned the cognitive advantages of bi/multilingualism, and nine of the twelve families expressed the desire for their child to learn additional, nonhome languages. 
In relation to specific languages, many parents noted the importance of learning French and English as the societal and school languages in Quebec. To explain their reasons for passing on their heritage language, six families cited their desire for their child to be able to communicate with grandparents or maintain contact with family in their home countries. Five families talked about passing on their culture and identity as heritage language speakers. One parent simply said that if children do not learn their heritage language, "C'est une richesse qu'ils perdent" [“They lose something valuable”].

When asked about how others reacted to their decision to raise their child bi/multilingually, parents responded that they received many positive messages about the advantages bi/multilingualism would offer their child. However, four families mentioned the concerns others expressed that the child would experience a language delay or that they would 'mix' languages. For example, one parent from a French-Korean household said, 'I also got criticisms from my mom and a little bit more old school people who are like, "Oh he's so melangé [mixed up]! . . . Poor kid he's never going to understand ever!"” Similarly, a parent who had immigrated from Colombia noted the concerns expressed by people from her home country who had little or no experience with simultaneous bilingualism:

On entend beaucoup de choses. C'est faux. Surtout quand la personne habite à la Colombie et peut-être il ne peut pas sortir beaucoup de son pays . . . . Et on entend qu'ils disent, "Oh pauvre le bébé! Qu'est-ce que tu fais? Il va mélanger tout! Il ne va parler bien à aucune!" ["We hear a lot of things. It's false. Especially when the person lives in Colombia and maybe can't leave the country a lot. And we hear them say, "Oh, the poor baby! What are you doing? He's going to mix up everything! He is not going to speak either [of the languages] well!']

Fourteen parents gave statements that dismissed these concerns. In relation to language delays, they repeated that even if a child did experience some language delay, 
once they caught up with their peers, the child would benefit from being bi/multilingual. In support of their arguments, they referred to empirically-based information, to their own experiences with bi/multilingualism, or to other families they knew who had successfully raised their children bi/multilingually or to adults they knew who spoke multiple languages. Two parents noted that as bilingual adults, they themselves sometimes 'mixed' languages, or translanguaged, in daily speech with no negative consequences. One parent said that she did not feel concerned if her child 'mixed' words in English and French at an early stage, as she explained that her partner was still 'mixing' as an adult: "Mon chum est bilingue, il a 35 ans, puis il mélange encore des mots et des phrases; ça ne me stresse pas" ["My partner is bilingual, he's 35 years old, and he still mixes words and sentences; it doesn't stress me'].

There was, however, a contrast between the optimism towards French/English bilingualism in comparison with beliefs about heritage language acquisition. Parents were less optimistic about their ability to fully support their children's heritage language development, and they were more concerned about their child's language mixing. Many pointed to the lack of exposure to the heritage language outside of the home through media, other speakers, or schooling. Five worried that they would be insufficient models of the heritage language, or they felt that it was difficult to be the only one responsible for passing on their heritage language. Four parents worried that their child might be unwilling to speak the heritage language, and they shared concerns about overloading their children with too many languages at once. One parent raising her child in English, French, and Spanish worried about the impact of a language delay or mixing on her child's progress at school in the future: 'But ya, right now she's mixing. She says in one phrases like three languages. 
Right now, it's cute but I'm like what's going to happen at school when she's gonna write, so that's my concern.'

\section{Language practices: A 'natural' approach}

When asked about their language use at home, ten families described adopting some form of the one-parent-one-language policy in their language use, although only two families described strict enforcement. The rest noted that they often made exceptions to the policy. Two families chose to speak only the heritage language in the home, and another single parent was using both English and French. All but four parents had also chosen to speak their dominant language with their child. This was either because they had read or been told that this was the most effective way to raise a child bilingually, or because it felt like the most 'natural' way to speak to their child. In fact, ten parents used words like 'natural,' 'go with the flow,' or 'instinct' to describe their beliefs about, and approach to, language use with their children.

Parents repeated that extensive, natural exposure to a language was most important for early childhood language acquisition. Eight parents referred to the notion of a critical period for language acquisition, comparing very young children to 'sponges'. As such, eleven parents described their attempts to organically expose their children to as many languages as possible. They talked about asking relatives and friends of the family to each speak their own dominant language with the child, even when that language was not a language used by the parent in the home. Nine of the twelve families had also chosen to send their children to a daycare where an additional, non-home language was spoken. For 
example, one mother from an English-French-Polish household had chosen to send her child to a French-Spanish daycare. She explained her philosophy:

...I'm always going to be go with the flow, take it as it comes. I wanna expose her as much as possible because I think when you learn languages later in life, you end up thinking more about grammar, versus it just like second-nature. . . . so I would want her to be exposed to the basics as a kid, and if she retains it then cool. If she doesn't, then I tried.

Although many of the parents were raising children who were still too young to speak more than a few words, four parents expressed concerns about having to 'push' their child to speak or learn a heritage language in the future. They worried that this would result in their child's disengagement, family disharmony, or rejection of the parent. A mother raising her child in English, French, and Spanish described a YouTube video in which other parents gave advice on raising a child bilingually, "I saw some parents that they really push, and I don't want that." Three parents shared their concerns about having to force their children to attend extra-curricular, weekend heritage language classes in the future.

Finally, parents often acknowledged that they mixed heritage languages with their children. Some parents seemed worried about the impact of this on their children's linguistic development. For instance, one parent who was raising her child in Hindi, Punjabi, English, and French sought information from the researchers on the negative impact of parental language mixing:

It's not every time I'm adding all the three languages because I don't know all the third language well. But say if I know 'à bientôt' so I say 'à bientôt' or "see you soon" or in Hindi we'll say something else but is it okay to do it for all the words and all the phrases we are using with her? Is it okay to do so?

Despite there being some concerns, fourteen parents dismissed concerns that their language mixing would make it more difficult for their children to distinguish between languages 
later on. One mother said, 'Je vais faire instinctivement comme ça puis je laisse les choses

aller.' ['I'm going to do things instinctively like that and let things go.'] Another parent

stated, 'My parents had a strong belief that if each person has their language and you don't mix, it will be better. But I don't think there's any evidence for that.' In the end, most parents believed their children would be able to distinguish between the household languages with or without strict language separation.

French through schooling, English through media

Ten of the twelve families stated that they would most likely place their child in a French language school. This was true even for parents whose child was eligible for English language schooling. Many parents explained that they believed French should be learned in school. Four parents stated that this was because it is more difficult and has more complicated grammar than English. Two parents were unhappy with their own level of French after studying it in English schools, and they believed that to reach a sufficient proficiency to function well in Quebec society, their child needed to be fully immersed in French at a French language school. One mother stated:

On a discuté très tôt de si notre fille va aller à l'école en français ou en anglais et puis [Father's name] était très frustré d'aller à l'école en anglais puis de perdre beaucoup son français. Fait qu'on s'est mis d'accord très tôt que notre fille elle allait à l'école en français. [We discussed early on about whether our daughter would go to French or English school and then [Father's name] was very frustrated to have gone to English school and lose his French. So we agreed early on that our daughter would go to French school.]

While agreeing that French should be learned in school, nine of the twelve families stated that they had decided to have their children learn English through exposure to media. A common refrain was that English could easily be 'picked up' through media, and several 
parents had already begun supporting their child's English acquisition via YouTube videos, cartoons, movies, and children's music. These contrasting approaches to language acquisition (school versus media exposure) may have been fueled by the lack of satisfactory options for French media or English schooling. One parent explained that there were few options for Quebecois French in local media, 'On a regardé sur Netflix. C'est juste l'anglophone, fait que là, il reste Radio Canada ou Télé Québec. Sinon ... la marché c'est vraiment qu'à Paris.' ['We looked on Netflix. It's just anglophone, so then there is only Radio Canada or Télé Québec left. Otherwise...the market is really only in Paris']. On the other hand, four parents stated that they were not enthusiastic about the English classes offered in French schools: 'C'est une inquiétude que j'ai pas nommé, c'est la qualité d'enseignement des langues secondes'. ['A concern that I haven't mentioned is the quality of second language instruction'.]

\section{Desire: More bilingual and heritage language options}

In one way or another, all parents stated a belief that French was important for their child's successful integration into Quebec society. Nevertheless, seven families expressed their desire for other types of schooling and for more English-French bilingual or heritage language resources. Some wished that bilingual public schooling was an option for everyone in Quebec. For example, one parent said, 'It annoys me this whole Quebec you need to go to French school.' Another parent stated,

I think there should be more schools, education, media that's geared toward bilingualism specifically because it's reality that there's English and French in Quebec and I think it could be interesting to mix it up. 
Yet another parent was considering leaving the province or home schooling her child to have more flexibility in her bilingual schooling options.

Three families discussed their wish for more opportunities for heritage language schooling. Without exception, all references to existing heritage language schools were negative. As noted earlier, some parents worried about forcing their children to go to school on weekends. Three families described a conflict between the values promoted by the heritage language schools and their own. For example, one mother did not want to send her child to Polish Saturday school, because it was Catholic, while she and her partner were atheist. Similarly, another mother said that she and her partner did not wish to send their child to Arabic school because the school's curriculum was based on Islam, and they were not religious. Other negative comments about the heritage language schools were that one day a week would not be sufficient to teach reading and writing (Mandarin), that the (Japanese) school was only appropriate for highly proficient children, or simply that no heritage language schools existed for the home language (Korean). Without satisfactory options for heritage language schooling, these parents often stated that they felt the burden was placed on their shoulders alone to insure their child's heritage language acquisition. One parent complained, 'But if you're in Montreal and if you want to push her to study Japanese, then...the parents need to take a lot of effort to do that, so it's another story.' Another parent referred to dual immersion options in the United States, En Californie, il y a [l'immersion en d'autres langues]. C'est duo-immersion. Because there's a pocket of Chinese kids in that area of the city. C'est cool, tu sais. Ils n'ont pas besoin eux de faire l'école du samedi. Ils peuvent quand même avoir leur langue. [In California, there is immersion in other languages. It's dual immersion. Because there's a pocket of Chinese kids in that area of the city. It's cool, you know. They don't have to go to school on Saturday. They can still have their language.] 
A final issue among the parents was the availability of informational and linguistic resources for raising their children. Seven parents noted that they had access to much concise, easily accessible information on parenting through websites, weekly emails, apps, a free local magazine for young parents, and talks offered at their local community centre or at the local government health centre. However, they would have liked the same type of access to information about bilingual parenting, and they had not found this.

Je ne me souviens pas d'avoir lu tant que ça une publication du gouvernement du Québec qui recommande quoi faire à des parents ici, surtout dans une ville comme Montréal. Aussi, ça devrait être accessible à tout le monde. [I don't remember having read such a publication from the government of Quebec that recommends what to do for parents here, especially in a city like Montreal. Also, that should be accessible to everyone.]

Although parents raising their children in English and French were satisfied with the amount of resources available separately in those two languages, they would have liked more bilingual books, something that they rarely found in local bookstores or libraries. One couple explained that it was difficult to maintain one-parent-one-language by translating a book written in a language other than the one they had chosen to speak with their child. They also wanted bilingual books that would allow them to focus on the same vocabulary in both languages: 'Avec la même histoire, elle va associer les mots à la même image.' ['With the same story, she will associate the words with the same image']. These parents also mentioned a desire for bilingual games and television shows, and one couple appreciated the increase in bilingual approaches to leading recreational activities in their part of town:

Most of the activities are in English, but...there's a lot more francophones in the West Island now so they're doing it like half-half. So, it's like OK, cool...if you don't understand it, they'll say it in the other language. So I think most people even in the West Island where it was mostly anglophone, they are switching to having it bilingual. It's just easier..." 
In contrast, as stated earlier, parents from heritage language households did not feel they had sufficient resources to support their child's learning. They desired resources that would allow them to offer more, and better, exposure to their language. Lack of exposure to the heritage language was their number one concern in relation to the potential success of their FLP. As with schooling, the parents felt that the burden of their child's heritage language acquisition lay on their shoulders. First, they wished for more books in their home language, noting the almost complete absence of those books from local libraries. Three families mentioned bringing books back from their heritage countries after visits or that they were using books they still had from their own childhood. Nevertheless, one mother noted that the Polish books from her childhood were not ones she would ever buy in a store because they were 'racist.'

A final resource that parents from both bilingual and heritage language households wished for was access to other families raising children bi/multilingually. In fact, some said that they had decided to participate in this focus group study to meet other parents in their situation. One parent explained that she would like to see 'how other people approach the same situation and what kind of challenges they encounter or what successes they've had like maybe you know once they have older kids.' The parents mentioned the possibility of community centre bi/multilingual parent groups or on-line forums where they could post questions. To offer their children more exposure, parents from heritage language households further wished for contact with families raising their children in the same language. For instance, one parent wished for, 'activities where we can involve our children 
in there too. Where they can be exposed to more languages as well and also...having a community.'

\section{Discussion}

\section{Convergence with official language policy}

In many ways, the parents' beliefs, language use, and plans for their child's future converged with Quebec's policy of interculturalism, which places French in a dominant public role and which officially supports cultural and linguistic diversity, particularly in the family domain. In line with official language policy, parents valued French language knowledge, viewed it as a source of cultural capital (Bourdieu, 1986), and believed their child required a strong background in the common public language through formal education. If the parents were not using French in the home, they planned to make up for it by putting their child in French schools even when they had eligibility for English schools. Meanwhile, they themselves were strongly supportive of cultural and linguistic diversity, but they primarily supported those languages in private, not public domains - in the home, with friends and family members.

The stated FLPs of the parents in this study did not support concerns that immigrants will tip Quebec towards English. In this, they did not align with some recent studies that have found support for this concern. For example, in a survey of 463 Quebecers under the age of 35, Oakes (2010) found respondents to be divided over whether EnglishFrench bilingualism was a threat to the survival of French, and a clear majority believed that English threatened the predominance of French. Moreover, in a multi-methodological study among 161 participants whose languages were English, French, and a language other 
than English or French, Author 4 (2014) found that all participants rated English more highly for status in both a survey and a matched guise experiment. The same trend was also found in more current survey research by Author 4 (in preparation).

Other Quebec-based researchers have challenged the validity of the threat to French, at least in educational contexts (Bourhis and Sioufi 2017). Shifting trends in school language choice among non-francophones indicate that at least in this respect, French is not in danger. Despite having the option to enrol their children in English schools, anglophone parents are increasingly choosing French schools: Between 2008 and 2013 alone, enrolment in the English school boards across the province dropped by $10.9 \%$, and since 1998 , at least 24 English schools have been closed in Montreal due to lack of enrolment (Luft 2013). Some studies of language use in Quebec's public domain have not found support for claims that the language's public presence is eroding. McAndrew et al. (2001) examined the force relative du français (FRF) or the relative strength of French use (in relation to English) by systematically observing outside-of-class interactions in 20 Montreal primary and secondary schools with high enrolment levels of heritage language students. The researchers also interviewed administrators, teachers, surveillance guards, and focus groups of students. They found that the students almost always chose to speak French at school. In a more recent study at one Montreal-area primary school, Author 3 (2017) found that students from heritage language households chose to speak French in almost every observed interaction.

The rise in bilingualism recorded by the 2016 Census (Statistics Canada 2016) included a 3\% increase in French-English bilingualism among Quebec anglophones (from 68 to $71 \%$ ) and a $1 \%$ increase among heritage language speakers (from 50 to $51 \%$ ). While 
the number of French-only mother tongue individuals decreased by $1 \%$, the percentage of bilingual French-other individuals also increased. While the numbers indicate proportionally fewer monolingual French individuals, they also indicate an increase in the amount and percentage of French-speaking people as well as a more bilingual society. It remains to be seen whether the increased English-French bilingualism reflects the beginnings of a societal language shift towards English (Fishman 1991), or the strengthening of French's position as an official and common public language.

\section{Divergence with official language policy}

Although the participants' home language use and long term planning aligned with official language policy, their beliefs often diverged from it. This was particularly true in relation to the heritage languages. Parents believed that formal, public sector support for bi/multilingualism would be beneficial for their families and for society. These parents wished for bi/multilingual public schooling, for libraries with media that would support their child's bi/multilingual literacy development, and for publicly-funded information for parents raising their children with more than one language. They believed that other languages could co-exist in a situation in which French is the lingua franca.

The idea that other languages can exist alongside French and English in Quebec society is strongly supported by research on societal language use (Lamarre 2013; Heller 2007). Second language education studies have long found oral and literacy development in children's home languages to be correlated with proficiency in the school language and academic achievement (August and Shanahan 2006; Collier and Thomas 2018; Goldenberg 2008; Riches and Genesee 2006). School-based studies from many contexts, including 
Montreal, have noted the profound impact that including learners' home languages in the curriculum can have on their classroom participation, literacy development, second language development, and academic achievement (Armand 2011; Cummins, Hu, Markus and Montero 2015; Gosselin-Lavoie and Armand 2015; Lory and Armand 2016; Prasad and Van Viegen 2019). However, some research indicates that this notion continues to be counter-intuitive to many teachers in Quebec contexts (Author 3 2017), and it is in opposition with official language policy in the province.

Many heritage-language parents in this study feared that without additional support, their families would experience language shift. Some wondered how they alone could serve as a sufficient linguistic model. Others worried that their children would be unable to read or write their heritage language. Still others feared that their children would eventually reject the heritage language in favor of French's higher status. Based on decades of research on intergenerational language shift (Fishman 1991, 2013; King and Fogle 2013; Spolsky 2012), their fears are well-founded. If immigrant parents' bi/multilingual FLPs are not offered external support in the form of media, schooling options, or expert parenting advice and encouragement, inter-generational home language shift may be inevitable, and linguistic diversity only a temporary and transitional phase for Quebec immigrants. This questions the compatibility of official language dominance with real cultural and linguistic diversity. Can true diversity exist in a society that offers concrete support for only one language?

In conclusion, findings from this small-scale study reflect positively on the intergenerational transmission of French in Quebec society. They also indicate the continued effectiveness of Quebec's official support for French, despite linguistic competition from 
English and the linguistic diversity that comes with the province's high immigration rates. However, this study raises concerns about the long-term prospects of heritage languages in Quebec society, and it questions the capability of Quebec's interculturalism policy - or at least the manner in which it is being interpreted and implemented - to simultaneously support both linguistic and cultural diversity as well as the current approach to promoting the role of French as the common public language. Moreover, parents in this study proposed the idea that there may be room for nuance in Quebec's official language policy. They believed that the government could offer more concrete support for their FLPs without endangering the role of French as dominant lingua franca. More broadly, our findings highlight how the beliefs, concerns, and decisions that parents in multilingual families make depend strongly on the community language context. 


\section{References}

Anctil, P. 1996. "La trajectoire interculturelle du Québec: la société distincte vue à travers le prisme de l'immigration." In Language, culture, and values in Canada at the turn of the 21 st century edited by A. Lapierre, P. Smart and P. Savard, 133-154. Ottawa, ON: International Council for Canadian studies/Carleton University Press

Armand, F. 2011. “Activités d'éveil aux langues, discrimination auditive et conscience plurilingue au préscolaire en contexte pluriethnique et défavorisé.” Le Langage et l'Homme 46(2): 55-72.

August, D. and T. Shanahan, eds. 2006. Developing literacy in second language learners. Report of the national literacy panel on minority-language children and youth. Mahwah, NJ: Lawrence Erlbaum.

Author 1. 2017.

Author 3. 2017.

Author 4. 2014.

Author 4. 2016.

Author 4. In preparation.

Bakhshaei, M. 2015. La scolarisation des jeunes québécois issus de l’immigration: un diagnostic. Montreal, QC : la Fondation Lucie et André Chagnon.

Bayley, R. and S. Schecter. 2003. Language socialization in bilingual and multilingual societies. Clevedon, UK: Multilingual Matters.

Bernard, A. 2008. “Les Repercussions Sociales et Politiques de la Loi 101.” In Le français au Québec: 400 ans d'histoire et de vie, new edition, edited by M. Plourde and P. Georgeault, 360-368. Montreal: Conseil supérieur de la langue française / Fides. 
Bouchard, G. 2012. L'interculturalisme: un point de vue québécois. Montréal, QC : Les Éditions du Boréal.

Bourdieu, P. 1986. "The forms of capital." In Handbook of Theory and Research for the Sociology of Education edited by J. Richardson. 241-258. New York: Greenwood.

Bourhis, R. and R. Sioufi. 2017. "Assessing forty years of language planning on the vitality of the Francophone and Anglophone communities of Quebec." Multilingua 36(5): 627661.

Collier, V. and W. Thomas. 2018. Transforming secondary education: middle and high school dual language programs. Albuquerque, NM: Fuente Press.

Crump, A. 2017. “'I speak all of the language!' Engaging in family language policy research with multilingual children in Montreal." In Family language policies in a multilingual world: Opportunities, challenges, and consequences edited by J.

MacAlistar and S. H. Mirvahedi. 154-174. London: Routledge.

Cummins, J., S. Hu, P. Markus, and K. Montero. 2015. "Identity texts and academic achievement: Connecting the dots in multilingual school contexts." TESOL Quarterly 49(3): 555-581.

Curdt-Christiansen, X. 2009. "Invisible and visible language planning: Ideological factors in the family language policy of Chinese immigrant families in Quebec." Language Policy 8(4): 351-375.

De Houwer, A. 2007. "Parental language input patterns and children's bilingual use." Applied Psycholinguistics, 27(3): 411-424.

Ferdman, B. 1990. "Literacy and cultural identity." Harvard Educational Review 60(2): $181-204$. 
Fereday, J. and E. Muir-Cochrane. 2006. "Demonstrating rigor using thematic analysis: A hybrid approach of inductive and deductive coding and theme development." International Journal of Qualitative Methods 5(1), 80-92.

Fishman, J. 1991. Reversing language shift. Clevedon: Multilingual Matters.

Fishman, J. 2001. Can threatened languages be saved? Reversing language shift revisited: a 21" century perspective. Clevedon, UK: Multilingual Matters.

Fogle, L. 2013. "Parental ethnotheories and family language policy in transnational adoptive families." Language Policy 12(1): 83-102.

Gafaranga, J. (2010). “Medium request: talking language shift into being." Language in Society, 39(2): 241-270.

Godfrey-Smith, L. 2015. “Reconciling language anxiety and the 'Montréal switch': an autoethnography of learning French in Montréal and negotiating my Canadian identity through language." Canadian Journal for New Scholars in Education 6(2): 9-15.

Goldenberg, C. 2008. “Teaching English language learners: what the research does - and does not-say." American Educator 33(2): 8-44.

Gosselin-Lavoie, C. and Armand, F. 2015. “Favoriser l'entrée dans l'écrit chez les jeunes enfants allophones." Canadian Journal for New Scholars in Education 6(2): 94-101.

Heller, M. 2007. Bilingualism a social approach. New York, NY: Palgrave Macmillan.

Institut de la Statistique du Québec. 2018. Le Québec chiffres en main. Québec. Retrieved from www.stat.gouv.qc.ca/droits auteur.htm.

Kay, B. January 19, 2011. "Barbara Kay: Multiculturalism 'is not a Quebec value'.” National Post. 
Kelleher, A. 2010. "What is a heritage language?" Heritage Briefs. Center for Applied Linguistics: http://www.cal.org/heritage/pdfs/briefs/What-is-a-Heritage-Language.pdf.

King, K. 2016. “Language policy, multilingual encounters, and transnational families.” Journal of Multilingual and Multicultural Development 37(7): 726-733.

King, K. and L. Fogle. 2006. “Bilingual parenting as good parenting: parents’ perspectives on family language policy for additive bilingualism.” International Journal of Bilingual Education and Bilingualism 9(6): 695-712.

King, K., and L. Fogle. 2013. "Family language policy and bilingual parenting.” Language Teaching 46(2): 172-194.

King, K. and L. Fogle. 2017. "Family language policy.” In Language Policy and Political Issues in Education, edited by T.L. McCarty and S. May, 315-327. New York, NY: Springer.

King, K., L. Fogle, and A. Logan-Terry. 2008. "Family language policy.” Language and Linguistics Compass, 2(5): 907-922.

Lamarre, P. 2013. "Catching "Montreal on the move" and challenging the discourse of unilingualism in Quebec.” Anthropologica 55(1): 41-56.

Lanza, E. and B. Svendsen. 2007. "Tell me who your friends are and I might be able to tell you what language(s) you speak. Social network analysis, multilingualism, and identity." International Journal of Bilingualism 11(3): 275-300.

Levine, M. 1990. The reconquest of Montreal: language policy and social change in a bilingual city. Philadelphia: Temple University Press. 
Little, S. 2017. "Whose heritage? What inheritance?: conceptualising family language identities." International Journal of Bilingual Education and Bilingualism, DOI: 10.1080/13670050.2017.1348463.

Lory, M.-P. and Armand, F. 2016. “Éveil aux langues et évolution des représentations d'élèves plurilingues sur leur répertoire linguistique." Alterstice 6(1): 27-38.

Luft, A. 2013. “The enrolment drop in Quebec's English schools.” Infographic taken from CTV Web site: https://montreal.ctvnews.ca/the-enrolment-drop-in-quebec-s-englishschools-1.1999020.

MacLennan, H. 1945. Two Solitudes. Markham, Canada: Fitzhenry \& Whiteside.

Marian, V., H. Blumenfeld and M. Kaushanskaya. 2007. “The language experience and proficiency questionnaire (LEAP-Q): assessing language profiles in bilinguals and multilinguals. Journal of Speech, Language and Hearing Research 50: 940-967.

Martinez-Roldan, C. and G. Malavé. 2004. "Language ideologies mediating literacy and identity in bilingual contexts." Journal of Early Childhood Literacy 4(2): 155-180.

Mc Andrew, M., C. Veltman, F. Lemire, and J. Rossell. 2001. "Les usages linguistiques en milieu scolaire pluriethnique à Montréal: situation actuelle et déterminants institutionnels." Revue Des Sciences de l'éducation 27(1): 105-126.

Oakes, L. 2010. "Lambs to the slaughter? Young francophones and the role of English in Quebec today." Multilingua 29(3-4): 265-288.

Oakes, L. and J. Warren. 2007. Language, citizenship and identity in Quebec. New York, NY: Palgrave Macmillan.

Okita, T. 2001. Invisible work: Bilingualism, language choice and childrearing in intermarried families. Amsterdam: John Benjamins. 
Patrick, D., G. Budach, and I. Muckpaloo. 2013. "Multiliteracies and family language policy in an Inuit community." Language Policy 12(1): 47-62.

Piller, I. and L. Gerber. 2018. "Family language policy between the bilingual advantage and the monolingual mindset." International Journal of Bilingual Education and Bilingualism, DOI: 10.1080/13670050.2018.1503227.

Prasad, G. and S. Van Viegen 2019. "Bridging Two Solitudes - Integrating Literacy Research across linguistic, cultural and disciplinary boundaries.” Language and Literacy 21(2): 1-4.

Ren, L. and G. Hu. 2013. "Prolepsis, syncretism, and synergy in early language and literacy practices: a case study of family language policy in Singapore." Language policy 12: $63-82$.

Revis, M. 2017. "Family language policy in refugee background communities: Towards a model of language management and practices." Journal of Home Language Studies 2: $40-62$.

Riches, C. and F. Genesee. 2006. Cross-linguistic and cross-modal aspects of literacy development. In Educating English language learners: A synthesis of research evidence edited by F. Genesee, K. Lindholm-Leary, W. Saunders and D. Christian, 64108. NY: Cambridge University Press.

Rocher, F., M. Labelle, A.-M. Field, and J.-C. Icart. 2007. “Le concept d'interculturalisme en contexte québécois: généaologie d'un néologisme.” Ottawa and Montréal: Research Centre on Immigration, Ethnicity and Citizenship.

Schwartz, M. and A. Verschik. 2013. Successful family language policy. New York, NY: Springer. 
Slavkov, N. 2017. "Family language policy and school language choice: pathways to bilingualism and multilingualism in a Canadian context." International Journal of Multilingualism 14(4): 378-400.

Smith-Christmas, C. 2016. Family language policy: maintaining an endangered language in the home. London, UK: Palgrave Pivot.

Smith-Christmas, C., M. Bergroth and I. Bezcioğlu-Göktolga. 2019. "A Kind of Success Story: Family Language Policy in Three Different Sociopolitical Contexts." International Multilingual Research Journal 13 (2): 88-101.

Spolsky, B. 2004. Language policy. Cambridge, UK: Cambridge University Press.

Spolsky, B. 2012. "Family language policy - the critical domain.” Journal of Multilingual and Multicultural Development 33(1): 3-11.

Statistics Canada. 2016. "Linguistic diversity and multilingualism in Canadian homes." Taken from https://www12.statcan.gc.ca/census-recensement/2016/as-sa/98-200x/2016010/98-200-x2016010-eng.cfm.

Stefanescu, A. and P. Georgeault, eds. 2005. Le français au Québec : les nouveaux défis. Quebec and Montreal: Conseil supérieur de la langue française and Fides.

Surrain, S. and G. Luk. 2017. "Describing bilinguals: a systematic review of labels and descriptors used in the literature between 2005-2015." Bilingualism: Language and Cognition. DOI: https://doi.org/10.1017/S1366728917000682.

Tuominen, A. 1999. "Who decides the home language? A look at multilingual families." International Journal of the Sociology of Language 140(1): 59-76.

Turgeon, L. and A. Bilodeau. 2014. "Minority nations and attitudes towards immigration: the case of Quebec." Nations and Nationalism 20(2): 317-336. 
Table 1.

Families' Self-Identified Language and Cultural Communities, and Mother's Highest Level of Education

\begin{tabular}{|c|c|c|c|c|}
\hline & Identification & $\begin{array}{l}\text { Total } \\
\qquad N\end{array}$ & $\begin{array}{c}N, \\
\text { EN-FR } \\
\text { families } \\
(/ 5) \\
\end{array}$ & $\begin{array}{c}N, \\
\text { Heritage language } \\
\text { families } \\
(/ 12) \\
\end{array}$ \\
\hline \multirow[t]{4}{*}{ Language Community } & Anglophone & 6 & 2 & 4 \\
\hline & Allophone & 5 & 1 & 4 \\
\hline & Francophone & 5 & 2 & 3 \\
\hline & Hispanophone & 2 & 0 & 2 \\
\hline \multirow[t]{7}{*}{ Cultural Community } & European & 5 & 1 & 4 \\
\hline & $\begin{array}{l}\text { Latin/Central/South } \\
\text { American }\end{array}$ & 4 & 0 & 4 \\
\hline & East and Southeast Asian & 3 & 0 & 3 \\
\hline & $\begin{array}{l}\text { Québecois/ North } \\
\text { American }\end{array}$ & 4 & 2 & 2 \\
\hline & Aboriginal & 1 & 1 & 0 \\
\hline & Arab & 1 & 0 & 1 \\
\hline & South Asian & 1 & 0 & 1 \\
\hline \multirow[t]{7}{*}{$\begin{array}{l}\text { Mother's Highest Level of } \\
\text { Education }\end{array}$} & Trade School Diploma & 1 & 0 & 1 \\
\hline & D.E.C. (Cégep) & 1 & 1 & 0 \\
\hline & Some College/University & 1 & 0 & 1 \\
\hline & Bachelor's degree & 5 & 1 & 4 \\
\hline & Graduate certificate & 1 & 1 & 0 \\
\hline & Master's degree & 8 & 2 & 6 \\
\hline & Doctoral degree & 1 & 0 & 1 \\
\hline
\end{tabular}


Note. "EN-FR" denotes families who speak English and French only. Families speaking any other language are included in the "Heritage language" column. Families may be part of more than one language/cultural community. One family was made up of two mothers, so we used the educational attainment of the primary caregiver. Demographic information is missing for 3/15 "Heritage language" families, and not included in this table. 


\section{Appendix A}

\section{Parent Interview Protocol}

\section{Personal Experience: Becoming Bilingual}

\section{(Question 1)}

Please share your experiences with languages growing up, both inside and outside your family.

\section{Attitudes: Bilingual Parenting Choices}

(Question 2)

Have you made any choices about the language or languages you would like your child to learn? How will your child learn those languages?

\section{Knowledge: Parenting Bilingual Children}

(Question 3)

There's lots of information and opinions out there about children being exposed to multiple languages when they're young. What have you heard, and what is your perspective?

\section{Concerns (announce final topic)}

\section{(Question 4)}

Do you have any concerns or worries related to your child's learning of different languages? Is there anything that could change your plans for your child?

\section{(Question 5)}

We're language researchers who want to do work that's relevant to parents. What's the most important resources you'd like to have, or questions you'd like to know an answer to? 